\title{
Comparative analysis of 1-D river flow models applied in a quasi 2-D approach for floodplain inundation prediction
}

\author{
Mauricio F. Villazón ${ }^{1,2}$, Luis M. Timbe ${ }^{3}$, Patrick Willems ${ }^{1}$ \\ ${ }^{1}$ Laboratory of Hydraulics, Faculty of Engineering, Katholieke Universiteit Leuven, Kasteelpark \\ Arenberg 40, Leuven, Belgium. \\ ${ }^{2}$ Laboratory of Hydraulics, Facultad de Ciencias y Tecnología, Universidad Mayor de San Simón, \\ Km 4,2 Avenida Petrolera, Cochabamba, Bolivia. \\ ${ }^{3}$ Earth and Environmental Sciences Research Group, Universidad de Cuenca, Av. 12 de Abril s/n, \\ Cuenca, Ecuador.
}

Autor para correspondencia: mauricio.villazon@fcyt.umss.edu.bo

Fecha de recepción: 16 de marzo 2013 - Fecha de aceptación: 17 de junio 2013

\begin{abstract}
A comparative analysis was performed of three 1-D river hydrodynamic models (Mike 11, InfoWorksRS and HEC-RAS) in a quasi 2-D setting. The study area was schematized either as a network of fictitious river branches or as storage areas. The models were run on a reduced area of the Dender River basin in Belgium, respectively for three historical flood events and eight synthetic events with a return period between 1 and 1000 years. The performance of the models were tested comparing simulated discharge, water level, inundation volume and inundated area. Results show that the three models and the two approaches used for the presentation of the floodplain lead to very similar results with a root mean square error of around $6 \mathrm{~cm}$ for the peak river levels and $2 \%$ for the river discharges. Despite the high accuracy of the water levels in the main river, inundation levels inside the floodplains have root mean square errors of around $25 \mathrm{~cm}$ during flood conditions.
\end{abstract}

Keywords: 1-D hydrodynamic models, quasi 2-D approach, floodplain modeling, hypsographic curve.

\section{RESUMEN}

En este estudio se realizó un análisis comparativo de tres modelos hidrodinámicos de ríos 1-D (Mike 11, InfoWorks-RS y HEC-RAS) con una configuración cuasi 2-D. La planicie de inundación fue esquematizada mediante una red de ramales ficticios o como áreas de almacenamiento. Los modelos se evaluaron en un área reducida de la cuenca del río Dender en Bélgica, para lo cual se simularon tres eventos de inundación históricos y ocho eventos sintéticos con períodos de retorno entre 1 y 1000 años, respectivamente. La eficiencia de los modelos se cuantificó comparando los valores simulados de caudal, nivel de la superficie del agua, volumen de inundación y área inundada. Los resultados muestran que los tres modelos y las dos configuraciones empleadas para la representación de las planicies aluviales dan resultados muy similares en el cauce principal del río, con un error cuadrático medio de alrededor de $6 \mathrm{~cm}$ para los niveles máximos y $2 \%$ para los caudales. A pesar de la alta precisión en el cauce, los niveles de crecida en la llanura aluvial tienen un error cuadrático medio mayor, de aproximadamente $25 \mathrm{~cm}$, en condiciones de inundación.

Palabras clave: Modelos hidrodinámicos 1-D, aproximación cuasi 2-D, modelación de planicies aluviales, curva hipsométrica. 


\section{INTRODUCTION}

Most hydrodynamic river models simulate water flow in one dominant spatial dimension and are called 1-D models. Combination of 1-D river flow models with geographic information systems (GIS) enables the prediction of the extent of floodplain inundations. Yang et al. (2006) showed the advantages for quickly generating and updating flood maps. Casas et al. (2006) applied a 1-D approach (HEC-RAS) to evaluate digital terrain models generated from different altimetric sources. Applications of 1-D river flow models with good results are shown by Helmiö (2005), Apel et al. (2004), among others. In those researches different modeling packages were applied, among which HEC-RAS (Pistocchi and Mazzoli, 2002; Sinnakaudan et al., 2002; Tun et al., 2006), Mike11 (Havnø et al., 1995; Van Kalken et al., 2005) and InfoWorks-RS (Pender and Neelz, 2007). The 1-D approach has the advantage of limited computational time, while alternative two-dimensional (2-D) approaches allow water level differences between the main river branch and the floodplain to be considered, as well as the 2-D flow in the floodplain (Hardy et al., 1999). An alternative approach, called quasi twodimensional (quasi 2-D) models, simulate the floodplains as storage reservoirs or a network of 1-D flood branches linked with the main river by means of spills (dike or embankment overflow units) or the combination of a 1-D model in the channel (numerical solution of the 1-D full hydrodynamic St. Venant equations) and a 2-D model to simulate the floodplains, by means of 2-D shallow water flow equations) (Rungø and Olsen, 2003; Timbe and Willems, 2007; Wermer et al., 2005). Comparisons of 1-D hydrodynamic models was performed by Crowder et al. (2003), Van Looveren et al. (2000) and Willems et al. (2000) using benchmarks. Comparison of the performance of 1-D versus 2-D and quasi 2-D models have been carried out by Markar et al. (2004), Wermer (2004), among others. One of these is the study by Horritt and Bates (2002), who compared HEC-RAS versus the more sophisticated 2-D models, such as TELEMAC-2D and LISFLOOD-FP, with HEC-RAS yielding unexpectedly good results. Pender and Neelz (2007) showed the advantage of the use of 1-D models for modelling large areas and for understanding flood defense schemes. Wermer (2004) demonstrated the advantage of the quasi 2-D schemes against the 1-D in the estimation of the conveyance for low over-bank flow.

From these researches, it can be concluded that the quasi 2-D approach is a good compromise between the 1- and 2-D methods, with relative low computational cost and acceptable accuracy, especially on very long river reaches. In the present study the performance of three 1-D river hydrodynamic modeling software packages applying two types of quasi 2-D approaches for modelling floodplains, the flood cells (FC) approach and the fictitious river branches (FRB) approach, were evaluated. In the FC approach, the floodplains are modelled by means of storage areas. The advantage of this approach over the 1-D model is that the overbank flow and the mass conservation in the floodplains are taken into account. The FC approach was also applied by Le Dimet et al. (2002) for data assimilation purposes. In the fictitious river branches (FRB) approach, the floodplains are modeled through a network of rivers linked by spills (Willems et al., 2002). The latter approach has the advantage that the momentum effect in the floodplains is included, which leads to improved results for floodplains with prominent flow dynamics. Whereas the FRB approach is implemented in InfoWorks-RS (Wallingford, 2006), Mike11 (DHI, 2008) and HEC-RAS River Analysis System version 4.0 (US-ACE, 2008), the FC approach is only implemented in the InfoWorks-RS software. The comparison is made in terms of river discharge, water level, flooded area, inundation level and water depth.

\section{DESCRIPTION OF THE STUDY AREA}

The study area is part of the Dender River basin in Belgium. The Dender River with a total length of $75 \mathrm{~km}$ (Fig. 1) is a tributary of the Scheldt River, draining a total area of $1384 \mathrm{~km}^{2}$ of which $708 \mathrm{~km}^{2}$ is located in the Flemish region. The Dender is regulated by gated weirs and sluices for navigational purposes. During winter the mean daily discharge is $25 \mathrm{~m}^{3} \mathrm{~s}^{-1}$. After storms, the flow can rise to over $100 \mathrm{~m}^{3} \mathrm{~s}^{-1}$. In the summer the mean daily discharge drops to $2,5 \mathrm{~m}^{3} \mathrm{~s}^{-1}$, but peak discharges between 25 and $30 \mathrm{~m}^{3} \mathrm{~s}^{-1}$ are frequently observed after long rainfall events. Only a small part of the Dender 
basin is considered for the present study, from the confluence between the Dender River and the main tributary, the Mark River, until the control structure Geraardsbergen, over a distance of approximately $5 \mathrm{~km}$ (Fig. 1). This part covers the area of the Overboelare floodplain on both the left and right side of the river Dender. The area is dominated by forest, bush and grazing meadows. The talweg elevation varies between 14,05 $\mathrm{m}$ above datum ( $\mathrm{AD}=$ standard Belgian "TAW" reference sea level) before the confluence with the Mark River to 12,07 m AD after the control structure in Geraardsbergen. River cross-sectional data are available approximately every $50 \mathrm{~m}$, and for the river floodplain a high resolution DEM based on Laseraltimetry (LiDAR) is available, with a horizontal resolution of $4 \mathrm{~m}$ (Fig. 1 and Fig. 6). The study area has been frequently flooded.
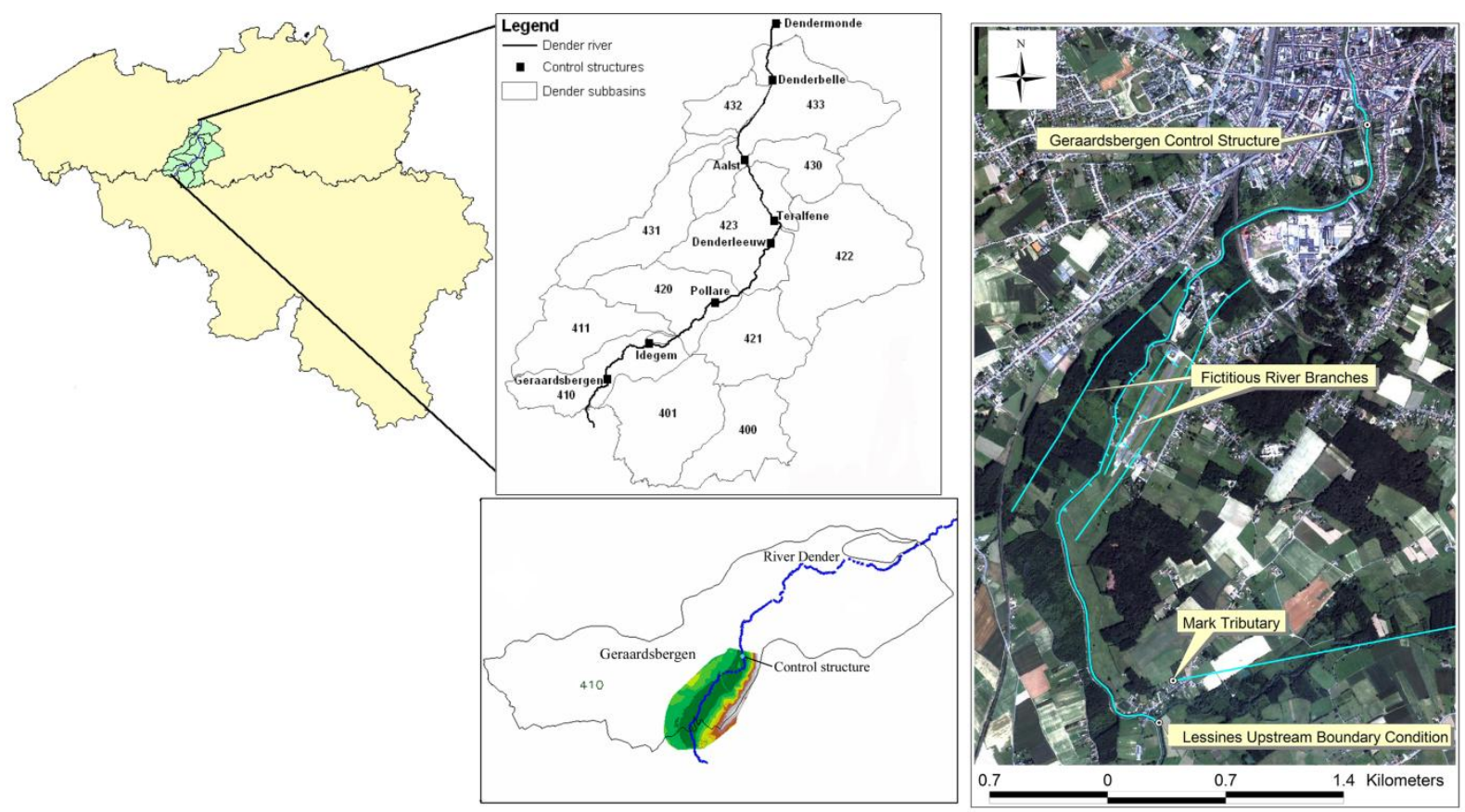

Figure 1. Location of the study area, in the catchment of Molenbeek-Geraardsbergen (hydrographic subcatchment zone 410).

\section{METHODS}

\subsection{Unsteady flow routing}

When applied with the fully dynamic approximation, the three software packages solve the 1-D SaintVenant equations, which express the conservation of mass and momentum of the water body, such that:

$$
\frac{\partial Q}{\partial x}+\frac{\partial A}{\partial t}=q
$$

and

$$
\frac{\partial Q}{\partial t}+\frac{\partial}{\partial x}\left(\frac{\alpha Q^{2}}{A}\right)+g A \frac{\partial h}{\partial x}+n^{2} \frac{g Q|Q|}{A R^{4 / 3}}=0
$$

where $\mathrm{Q}$ is the discharge $\left(\mathrm{m}^{3} \mathrm{~s}^{-1}\right), \alpha$ the vertical velocity distribution coefficient, A the cross section area $\left(\mathrm{m}^{2}\right), \mathrm{g}$ the gravitational acceleration $\left(\mathrm{m} \mathrm{s}^{-2}\right), \mathrm{x}$ the river distance in the downstream direction $(\mathrm{m})$, $\mathrm{h}$ the stage above datum $(\mathrm{m}), \mathrm{t}$ the time $(\mathrm{s}), \mathrm{n}$ the Manning coefficient $\left(\mathrm{s} \mathrm{m}^{-1 / 3}\right), \mathrm{q}$ the lateral inflow $\left(\mathrm{m}^{2}\right.$ $\mathrm{s}^{-1}$ ), and $\mathrm{R}$ the hydraulic radius (m). 

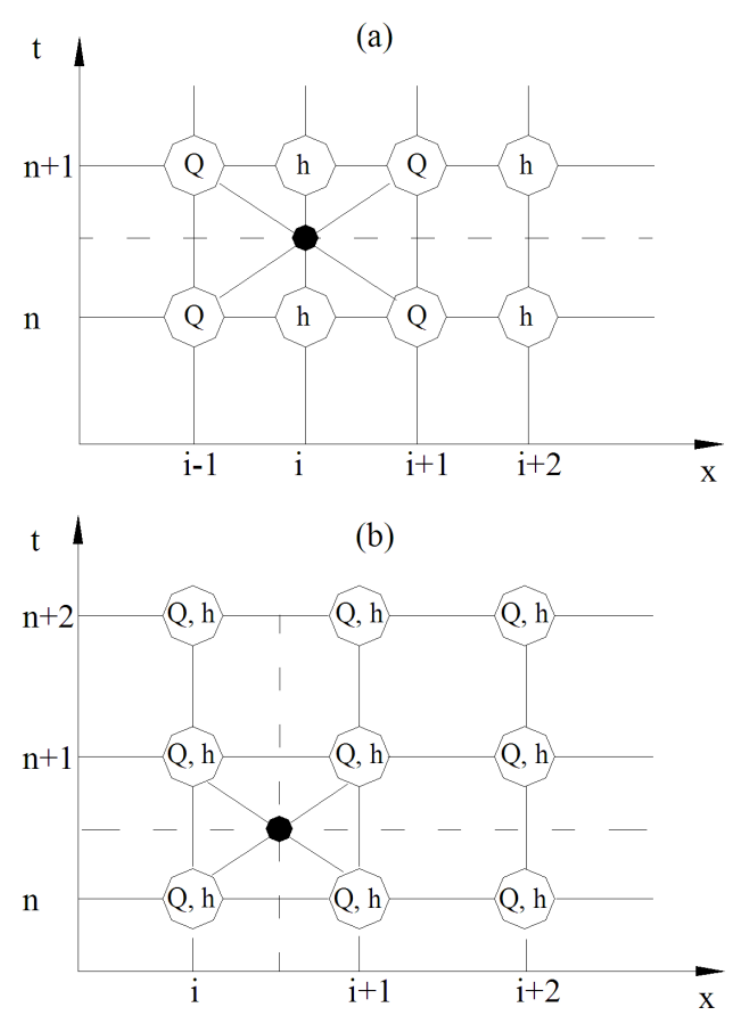

Figure 2. Implicit finite difference schemes: (a) Abbott and Ionescu, and (b) Preissmann.

Solutions for the Eqs. (1) and (2) in Mike11 are based on the implicit finite difference scheme developed by Abbott and Ionescu (1967). The computational grid consists of alternating Q and $h$ points (Fig. 2a), solved with a double sweep algorithm (DHI, 2008). InfoWorks-RS employs the Preissmann implicit-finite difference scheme which is popularly referred to as the 4-point Box scheme (Preissmann, 1961). The computational grid consists of $\mathrm{Q}$ and h nodes at the same location (Fig. 2b), and is solved with a powerful sparse matrix (Wallingford, 2006). HEC-RAS applies also the 4-point Box scheme linearizes the finite difference equations using the Preissmann method as reported by Liggett and Cunge (1975), and Chen (1973). The 1-D shallow water equations are applied in the floodplains for the FRB approach.

\subsection{Lateral spill}

To model a lateral spill between the main river and the floodplain in the quasi 2-D approach, in Mike11 a special type of channel is defined, the so-called "link channel" (Fig. 3a). The link channel is defined by two " $h$ " points (water level calculation nodes), one along the main river and one along the floodplain. In Fig. 3a these points are I1 and I2. The discharge is calculated using the water levels in points I1 and I2 applying a Q-h relation when free overflow occurs. When submerged flow occurs the discharge calculation takes place during the simulation because the discharge is a function of both upstream and downstream water levels. In both cases, the irregular shape of the spill is considered (DHI, 2008).

In InfoWorks-RS the lateral spills are simulated by "spill units" and in HEC-RAS by "lateral weirs". In both modeling packages water levels and discharges are calculated in every point of the computational grid. In Fig. $3 \mathrm{~b}$ the spill is located between 4 points, respectively B, C, F and G. InfoWorks-RS assumes a straight water surface profile between the points $\mathrm{B}$ and $\mathrm{C}$ and the points $\mathrm{F}$ and G; the water level is interpolated linearly and the spill unit calculates the flow over the banks as an irregular weir by splitting the calculation to determining flows over segments using an integrated form of the weir equation for dry, free and drowned, forward and reverse modes (Fig. 3b). For the FC approach the same procedure is applied but the water level inside the floodplain is assumed horizontal 
and is calculated as a function of the volume of water that passes over the spill applying a hypsographic curve (Fig. 3c).

(a)

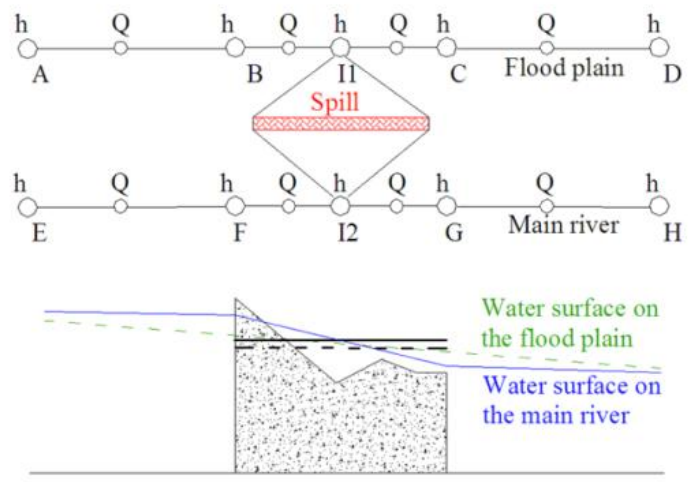

(b)

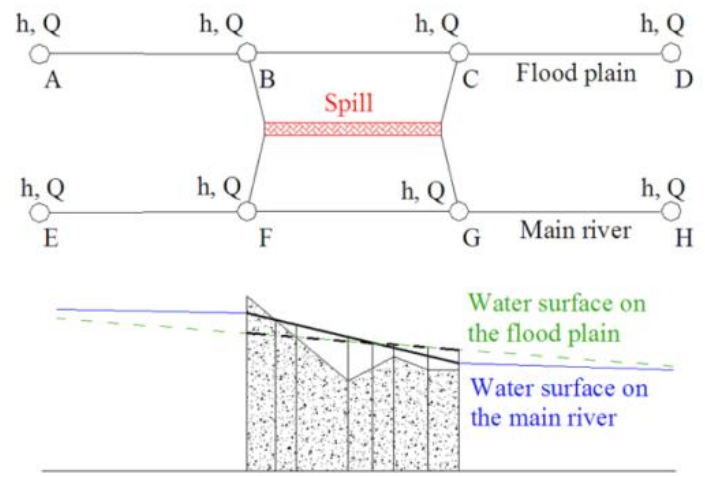

(c)
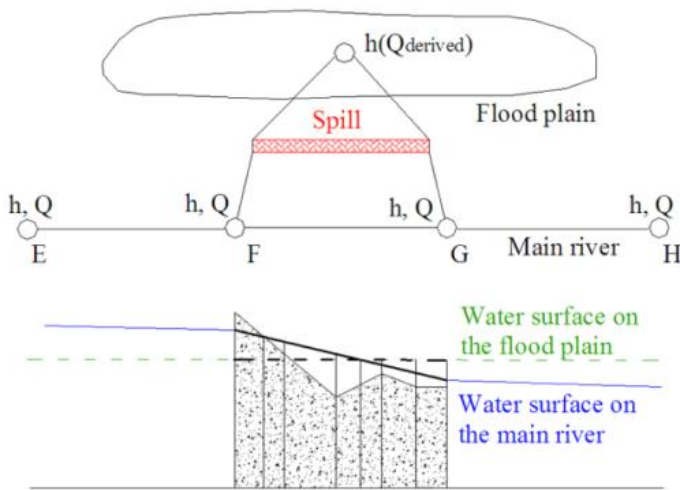

Water surface on the flood plain

Water surface on the main river

Figure 3. Schematic presentation of a lateral spill in (a) Mike11 (link channel FRB approach), (b) InfoWorks-RS and HEC-RAS (FRB approach), and (c) InfoWorks-RS (FC approach).

In HEC-RAS the overflow equation is derived for a sloping weir and sloping water surface by integrating the standard weir equation, similar as in InfoWorks-RS. The main difference is that HECRAS uses a submerged factor (FHWA, 1978) and InfoWorks-RS uses a modular limit to differentiate the condition of flow (Evans and von Lany, 1983). 


\subsection{NAM rainfall-runoff}

Rainfall-runoff input in the hydrodynamic river model is simulated by the NAM model, standard module of the Mike11 software. The NAM model is a deterministic conceptual model that simulates the rainfall-runoff process of a river catchment in a spatially lumped way. It simulates the rainfallrunoff process taking into account the water content in four different and mutually interrelated storages which represent physical elements of a catchment, respectively the surface, the rootzone, the groundwater and the snow storage. The input data for this model consist of timeseries of climate data, mainly rainfall $(\mathrm{mm})$ and potential evapotranspiration $(\mathrm{mm})$, which are calculated based on pan evaporation data by applying an empirical reduction coefficient. The latter reduction coefficient was calibrated to simultaneous pan evaporation data and potential evapotranspiration estimates (based on the Penman-Monteith model) for a limited data period. The model output is calibrated against flow timeseries obtained at river gauging stations (DHI, 2008).

\section{MODEL IMPLEMENTATION}

A Mike11 quasi 2-D model implementation, based on the FRB approach, was developed for the whole Dender basin by Willems et al. (2002a). Rainfall-runoff discharge series were generated by the NAM model. The hydrological model was calibrated for the gauged subcatchments in the Dender basin by Rombauts and Willems (2004). This calibration was done based on 8 limnigraphic stations, with hourly river flow data for the period 1986-2002, distributed over the basin. Relationships were identified and calibrated between the NAM model parameters and catchment characteristics, in order to determine the model parameters of the ungauged catchments. The runoff results of the hydrological model were used as input in the hydrodynamic river model as lateral inflow. The hydrodynamic model was calibrated and validated based on hourly water level data, period 1987-2002, up and downstream of the 8 hydraulic control structures along the Dender river (Fig. 1). Floodplains were implemented along the Dender for areas that can flood up to return periods of 1000 years, based on composite hydrograph simulations as discussed hereafter. A digital elevation model (DEM) with a spatial resolution of $4 \mathrm{~m}$ was used to extract cross-sections along the floodplains for the quasi 2-D implementation and for the flood mapping. Evaluations of the flood model were derived from hydrometric data and historical flood maps obtained from field inspection and ERS-SAR satellite images (Timbe et al., 2005).

The simulation results of the Mike11 FRB model approach, applied to the entrie Dender River basin, are taken as the boundary condition at the upstream side, and the weir regulation scheme of the hydraulic control structure (weir-sluice combination) in Geraardsbergen as the boundary condition at the downstream end of the study area. For the reduced area, model evaluation was conducted on the basis of the water level measurements upstream of the Geraardsbergen control structure (Fig. 1). Water level measurements were taken 3 times per day in 1993, respectively at 8:00, 12:00 and 16:00. For the remaining period water levels were recorded hourly.

Parallel to the Mike11 model (Fig. 4a), a HEC-RAS (Fig. 4b) and an InfoWorks-RS model were developed. In InfoWorks-RS both the FRB (Fig. 4c) and FC (Fig. 4d) approaches were implemented. For the FRB implementation, the cross section data of the river and fictitious floodplain branches (implemented approximately every $50 \mathrm{~m}$ ) are taken identical in the InfoWorks-RS, HEC-RAS and Mike11 models. In this way, the topography in the floodplains and the FRB implementation is done identical for each modeling approach, avoiding that the results are affected by subjectivities in the model set-ups. For the spills between the Dender and the floodplains, the standard link channels in Mike11 (DHI, 2008), spill units in InfoWorks-RS, lateral weirs in HEC-RAS (US-ACE, 2008) were applied, and the default values were used for the discharge and head loss coefficients.

In all model set-ups and runs the same Manning coefficients were used, varying in each cross section between 0,04 and $0,06 \mathrm{~s} \mathrm{~m}^{-1 / 3}$. Also the discharge and head loss coefficients for the Geraardsbergen control structure were selected such that they led to identical relations between discharge and upstream water level. The latter is done calibrating the discharge and head loss coefficients in Mike11 by minimizing the mean squared error with the water level measurements at the 
Geraardsbergen control structure, and afterwards in the other models by minimizing the mean squared error of the hourly flow estimates for the same flood events. In other words by comparing InfoWorksRS with Mike11, and HEC-RAS with Mike11 to obtain the corresponding InfoWorks-RS and HECRAS coefficients. The final values of head loss coefficients for each of the three software packages are listed in Table 1.

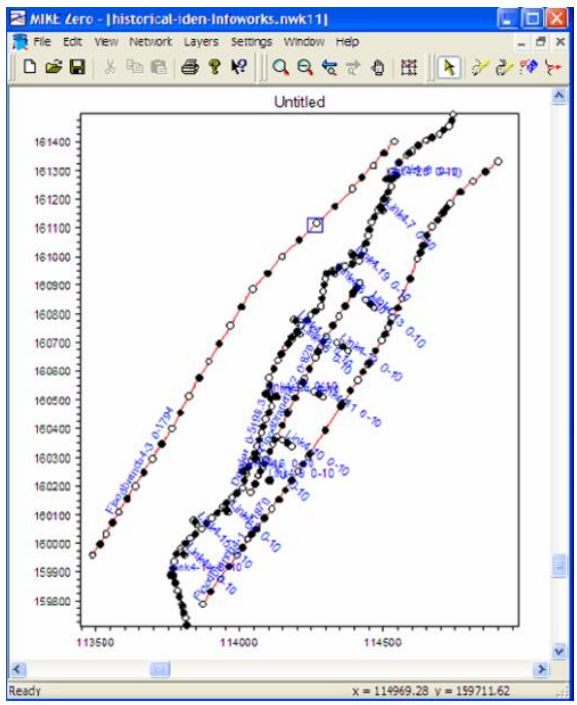

(a)

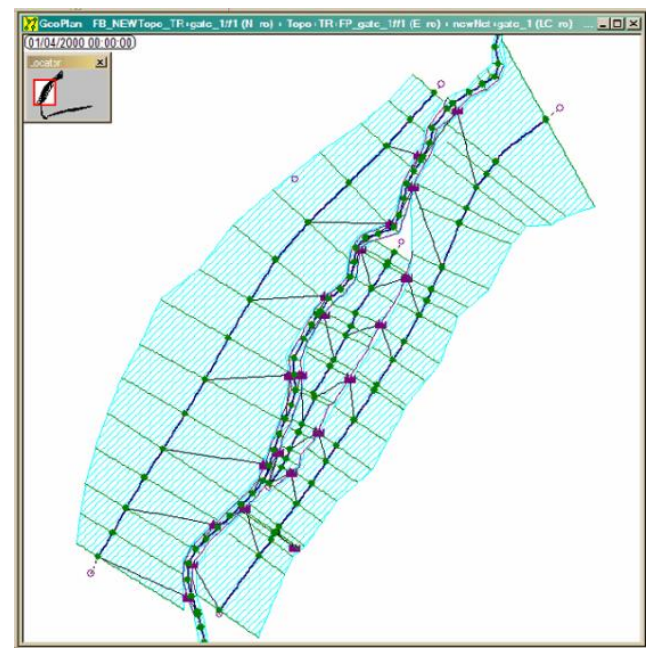

(c)

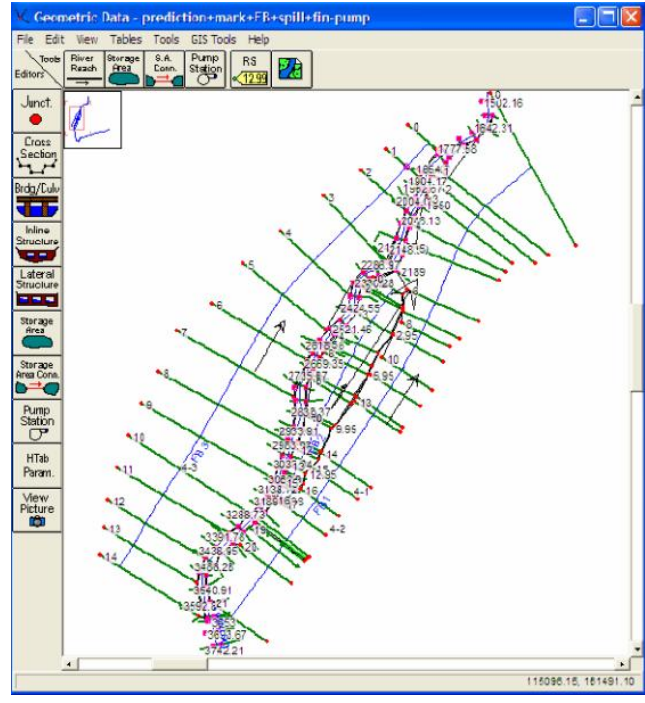

(b)

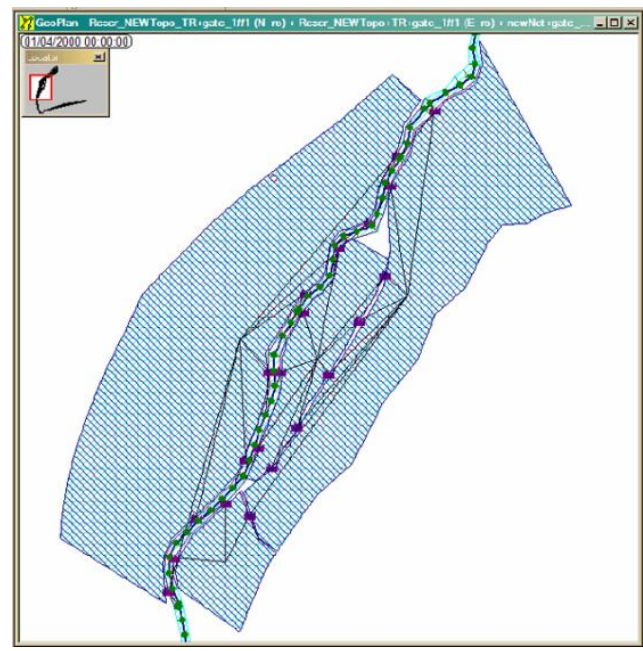

(d)

Figure 4. River networks: (a) Mike11, (b) HEC-RAS, (c) InfoWorks-RS following the fictitious river branches (FRB), and (d) InfoWorks-RS flood cells (FC) approaches, respectively.

The different models were implemented such that differences due to input data and calibration are kept to a minimum. After implementation of the models, two types of simulations were carried out:

- Simulations of the historical flood events in 1993, 1995, 2002-2003 and other events in 1993, 1998 and 1999. The specific duration of each event is presented in Table 2. The first three events are characterized for reported flood occurrence in the Overboelare region, and the other events are chosen to investigate the performance of the model under lower flow conditions.

- Simulations with synthetic hydrographs (hydrographs representative for given return periods in the range from 1 to 1000 years). 
Table 1. Head loss coefficients for the Geraardsbergen control structure.

\begin{tabular}{ll}
\hline Mike11 & 0,75 \\
Positive flow - Inflow & 0,75 \\
Negative flow - Inflow & 1 \\
Positive flow - Outflow & 1 \\
Negative flow - Outflow & 1,2 \\
Positive flow - Free Overflow & 1,2 \\
Negative flow - Free Overflow & \\
\hline InfoWorks-RS & 0,9 \\
Modular limit & 0,9 \\
Throat & 0,85 \\
Forward gate & 1 \\
Reverse gate & \\
\hline HEC-RAS & Sharp crested \\
Gate weir shape & 1,95 \\
Gate weir coefficient & 1,44 \\
Broad crest coefficient & \\
\end{tabular}

Table 2. Events considered for model calibration.

\begin{tabular}{ll}
\hline Flood events & 1 December 1993 to 31 December 1993 \\
& 10 January 1995 to 28 February 1995 \\
& 15 December 2002 to 15 January 2003 \\
\hline Other events & 7 January 1993 to 31 January 1993 \\
& 09 October 1998 to 10 November 1998 \\
& 02 January 1999 to 10 February 1999 \\
\hline
\end{tabular}

The form of the synthetic hydrographs are 'composite hydrographs' derived for each subbasin on the basis of an extreme value analysis applied to a longterm timeseries of rainfall-runoff discharges covering the period between 1967 to 2003 (Willems and Rombauts, 2004). The timeseries were generated by the lumped conceptual hydrological model NAM, applied to the subbasins. Flood frequency distributions were derived for the rainfall-runoff discharges in a range of aggregation levels or concentration times which vary from 1 hour to 15 days. The composite hydrographs were derived from these distributions in such a way that the average discharge equals a specific return period for all central durations in the hydrograph. They have the important feature that river states with the same safety level at all locations along the river can be derived by one single shortterm simulation. The accuracy of the composite hydrographs has been tested by Vaes et al. (2000). The composite hydrographs are applied in this study to simulate in an accurate and easy way specific safety levels along the river.

\section{MODEL VALIDATION}

The following statistical critera were used for the evaluation of the performance of the models: RMSE (Root Mean Square Error), $\mathrm{R}^{2}$ (Determination Coefficient), EF (Model Efficiency, Eq. 3, Nash and Sutcliffe, 1970), and Model Skill (Eq. 4) presented by Wilmott (1981) and applied by Warner et al. (2005).

$$
E F=1-\frac{\sum_{i=1}^{n}\left[O_{i}-P_{i}\right]^{2}}{\sum_{i=1}^{n}\left[O_{i}-\bar{O}\right]^{2}}
$$




$$
\text { Skill }=1-\frac{\sum_{i=1}^{n}\left(P_{i}-O_{i}\right)^{2}}{\sum_{i=1}^{n}\left(\left|P_{i}+\bar{O}\right|+\left|O_{i}-\bar{O}\right|\right)^{2}}
$$

where $\mathrm{O}_{\mathrm{i}}$ is the $\mathrm{i}$-th observed value, is the average of the observed values, and $\mathrm{P}_{\mathrm{i}}$ is the $\mathrm{i}$-th simulated value.

Table 3. Evaluation of long time river level series, upstream of the control structure.

\begin{tabular}{ccccccc}
\hline Events & Model & Approach & RMSE & EF & $\mathrm{R}^{2}$ & Skill \\
\hline \multirow{4}{*}{ Flood events } & Mike11 & FRB & 0,154 & 0,746 & 0,879 & 0,926 \\
& InfoWorks-RS & FRB & 0,177 & 0,664 & 0,865 & 0,911 \\
& HEC-RAS & FRB & 0,145 & 0,775 & 0,881 & 0,933 \\
& InfoWorks-RS & FC & 0,161 & 0,721 & 0,868 & 0,924 \\
\hline \multirow{3}{*}{ Flood events + } & Mike11 & FRB & 0,144 & 0,676 & 0,841 & 0,904 \\
other events & InfoWorks-RS & FRB & 0,167 & 0,607 & 0,813 & 0,881 \\
& HEC-RAS & FRB & 0,137 & 0,710 & 0,848 & 0,908 \\
& InfoWorks-RS & FC & 0,152 & 0,642 & 0,822 & 0,899 \\
\hline
\end{tabular}

Table 3 lists for each of the three flood events the values of EF and Skills greater than 0,65 and 0,90 , and EF and Skills values greater than 0,60 and 0,88 considering all the simulated events. Taking into account that the $\mathrm{R}^{2}$ values are greater than 0,80 , it is possible to conclude that the performance of the models for all analyzed events (flood and other events) is acceptable. Perfect agreement of modeled and observed water levels is not possible, due to the manual operation of the Geraardsbergen control structure. The evaluation parameters in Table 3 depict the model accuracy for predicting water levels. In Fig. 5 the water level results in meters AD, upstream of the control structure, are presented for the historical flood period of December 2002. Table 4 presents the dates of the highest water levels, the measured and modeled peak water levels.

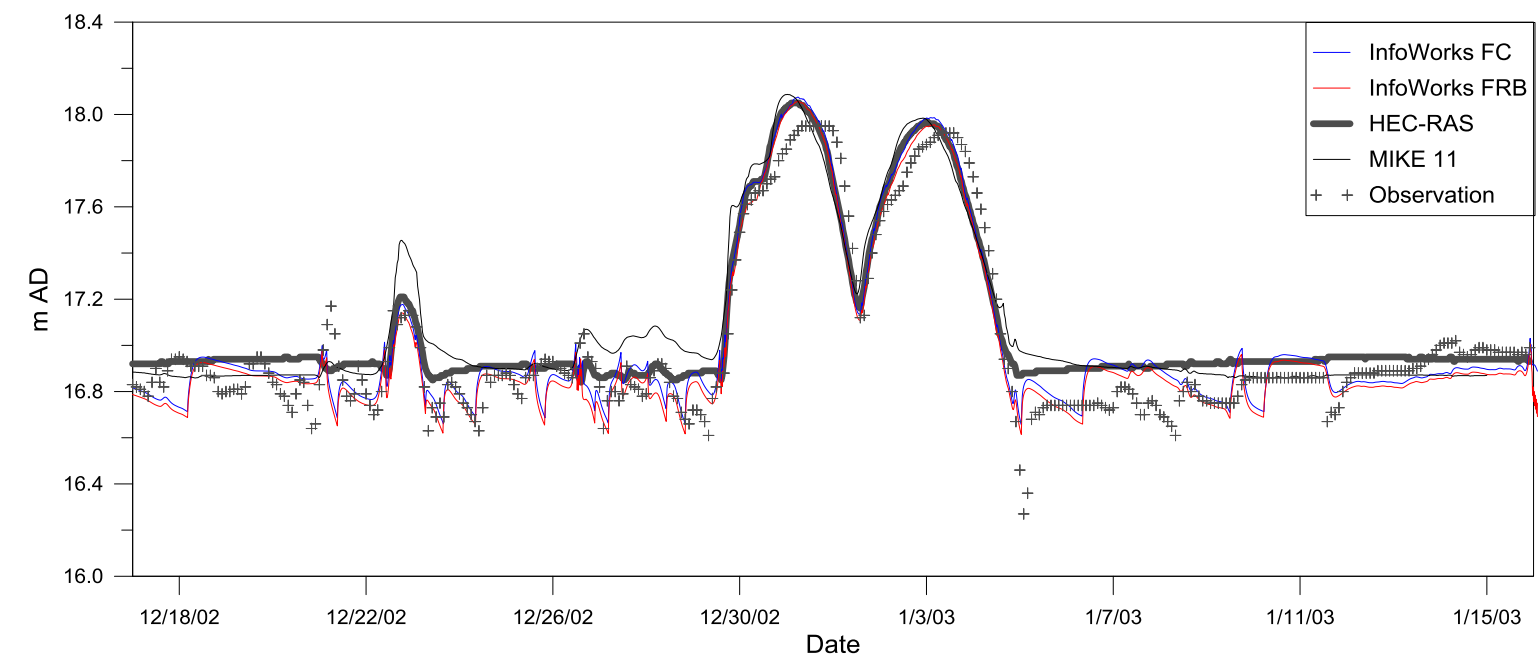

Figure 5. Plot of simulated and measured water level timeseries, for the historical flood period of December 2002.

The determination coefficient $\left(\mathrm{R}^{2}\right)$ of modeled versus measured peak water levels is 0,977 for the Mike11 model, 0,987 for the InfoWorks-RS model with FRB approach, and 0,989 for the HEC-RAS model. The determination coefficient of the Mike11 results against InfoWorks-RS with FRB approach is 0,994 , while the one for Mike11 against HEC-RAS is 0,993. The high $\mathrm{R}^{2}$ values (close to 1 ) and the small Root Mean Square Error (RMSE) values indicate that the simulation results of the three models are highly accurate and comparable. The fact that model inputs and calibration parameter values have 
been taken identical as much as possible, may have contributed to this conclusion. It, however, does not necessarily lead to similar model accuracies due to differences in the solution of the hydrodynamic equations and the spill schematizations.

For all simulated events, the RMSE for the peak water level in the three models is less than $8 \mathrm{~cm}$ (6,9 $\mathrm{cm}$ for Mike11, 6,3 cm for InfoWorks-RS FRB, $5 \mathrm{~cm}$ for HEC-RAS, and 6,2 cm for InfoWorksRS FC). The same magnitudes of errors are reported by Willems et al. (2000).

Table 4. Peak river level results for the historical flood events.

\begin{tabular}{|c|c|c|c|c|c|}
\hline \multirow{3}{*}{ Date } & \multicolumn{5}{|c|}{ Water level, meters above datum (m AD) } \\
\hline & \multirow[b]{2}{*}{ Measured } & \multicolumn{4}{|c|}{ Simulated } \\
\hline & & $\begin{array}{l}\text { Mike11 } \\
\text { FRB }\end{array}$ & $\begin{array}{c}\text { InfoWorks- } \\
\text { RS FRB }\end{array}$ & $\begin{array}{c}\text { HEC-RAS } \\
\text { FRB }\end{array}$ & $\begin{array}{c}\text { InfoWorks- } \\
\text { RS FC }\end{array}$ \\
\hline \multicolumn{6}{|l|}{ Flood events } \\
\hline 21/12/1993 & 17,56 & 17,54 & 17,49 & 17,54 & 17,51 \\
\hline 23/01/1995 & 17,58 & 17,58 & 17,53 & 17,57 & 17,57 \\
\hline 30/01/1995 & 17,78 & 17,83 & 17,82 & 17,84 & 17,84 \\
\hline $31 / 12 / 2002$ & 17,95 & 18,09 & 18,06 & 18,05 & 18,08 \\
\hline $3 / 1 / 2003$ & 17,92 & 17,98 & 17,96 & 17,97 & 17,99 \\
\hline \multicolumn{6}{|l|}{ Other events } \\
\hline $1 / 12 / 1993$ & 17,12 & 17,19 & 17,08 & 17,14 & 17,07 \\
\hline $1 / 11 / 1998$ & 17,36 & 17,42 & 17,29 & 17,33 & 17,32 \\
\hline 27/01/1999 & 17,36 & 17,44 & 17,31 & 17,38 & 17,35 \\
\hline RMSE (m) & & 0,069 & 0,063 & 0,048 & 0,062 \\
\hline $\mathrm{R}^{2}$ & & 0,977 & $0, .987$ & 0,989 & 0,993 \\
\hline
\end{tabular}

\section{INTERCOMPARISON OF MODEL RESULTS}

Intercomparison of the different models and model set-ups of the floodplains is based on the comparison of peak water levels and discharge values along the Dender, the inundation levels along the floodplains, the flooded areas and the flooded volumes. The comparison of the three models and floodplain set-up is conducted for the historical events and the synthetic composite hydrographs with a $1,2,5,10,25,50,100,500$ and 1000 years return period.

\subsection{Peak river levels}

Table 4 shows the results for the peak water levels in the Dender upstream of the Geraardsbergen control structure. The period of January 1993 represents rather low water levels without significant flow peaks. For the flood events peak water levels are presented and the RMSE calculated. Values similar to the results after model validation were derived (in the range of 5 to $7 \mathrm{~cm}$ ). A similar RMSE value (4 cm) was found by Mirosław-Światek et al. (2003) applying the HEC-RAS model.

\subsection{Peak river discharges}

Peak discharge values for the historical events upstream of the Geraardsbergen control structure are shown in Table 5. The RMSE is less than $1,5 \mathrm{~m}^{3} \mathrm{~s}^{-1}$. The peak discharge values predicted by InfoWorks-RS FRB are on average 1,72\% different from the values generated by the Mike11 model, $1,03 \%$ in HEC-RAS, and 1,85\% in InfoWorks-RS FC. Markar et al. (2004) reported differences in the range of 14 to $20 \%$ for InfoWorks-RS and Mike11 between predicted and recorded peak discharges. When model calibration would not have been pursued with maximum consistency, the mean error of $1,8 \%$ could have gone up to $10 \%$. Willems et al. (2000) also found differences in the order of 5 to $10 \%$ of the total discharge. 
Table 5. Peak river discharge results for the historical events.

\begin{tabular}{lcccc}
\hline \multirow{2}{*}{$\begin{array}{l}\text { Date } \\
\text { flood events }\end{array}$} & Mike11 & InfoWorks-RS & HEC-RAS & InfoWorks-RS \\
& FRB & FRB & FRB & FC \\
\hline $21 / 12 / 1993$ & 57,07 & 58,76 & 58,08 & 58,04 \\
$23 / 01 / 1995$ & 58,74 & 60,30 & 59,60 & 59,76 \\
$30 / 01 / 1995$ & 72,20 & 72,61 & 72,71 & 70,71 \\
$31 / 12 / 2002$ & 87,33 & 85,83 & 87,30 & 85,71 \\
$3 / 1 / 2003$ & 81,26 & 79,30 & 80,51 & 78,91 \\
\hline Other events & & & & \\
\hline $1 / 12 / 1993$ & 43,04 & 42,52 & 42,69 & 42,51 \\
$1 / 11 / 1998$ & 49,08 & 48,90 & 48,54 & 48,90 \\
$27 / 01 / 1999$ & 51,05 & 50,00 & 50,40 & 49,81 \\
\hline RMSE $\left[\mathrm{m}^{3} \mathrm{~s}^{-1}\right]$ & & 1,27 & 0,65 & 1,33 \\
$\mathrm{R}^{2}$ & & 0,993 & 0,998 & 0,995 \\
\hline
\end{tabular}

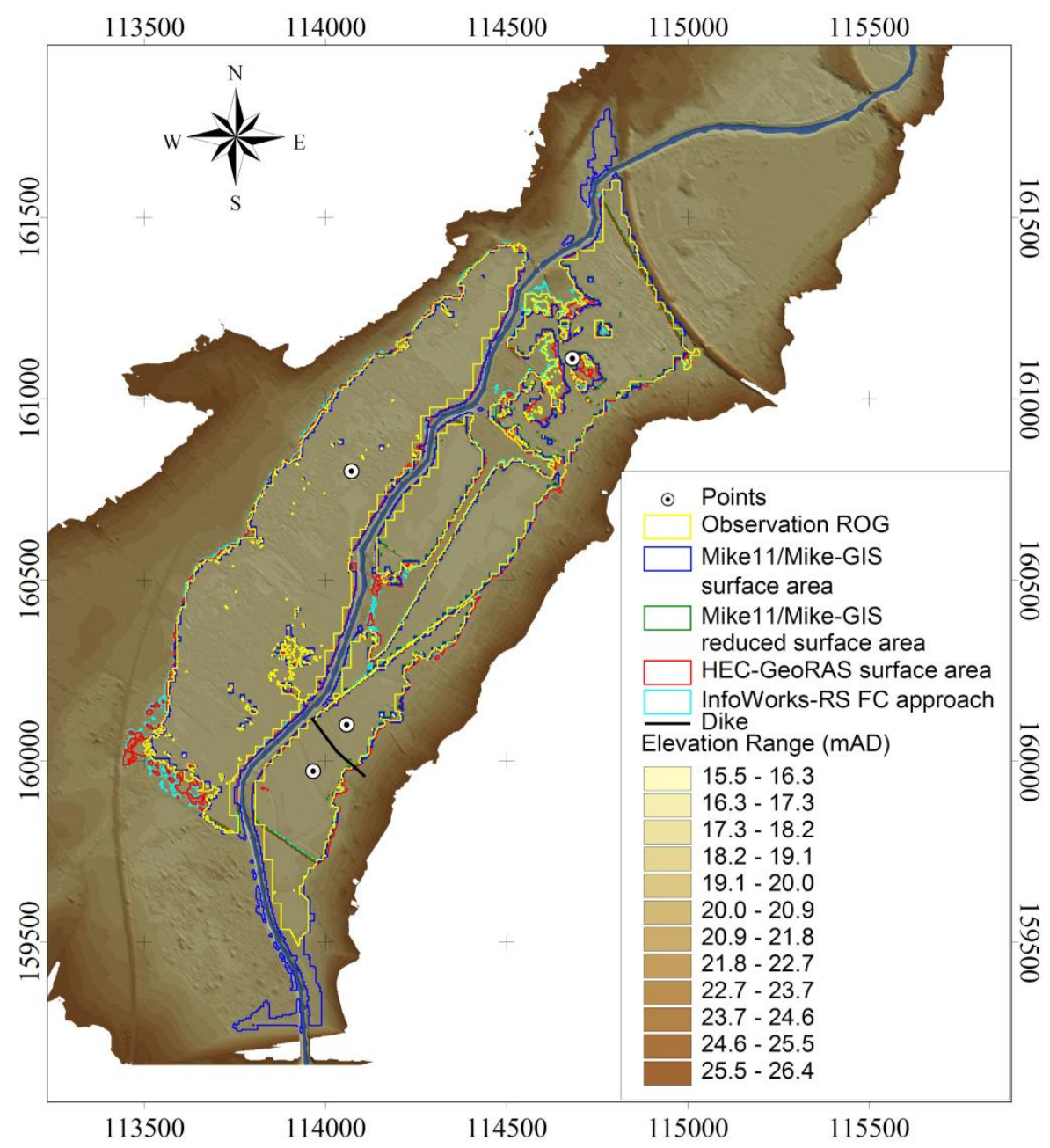

Figure 6. Overlay of DEM, the four points evaluated and historical and simulated flood maps for the Overboelare region (historical flood event of January 1995).

\subsection{Peak inundation levels and depths inside the floodplains}

For the evaluation of the water levels inside the floodplains, four points (three in the right floodplain and one in the left floodplain) were considered: one upstream and one downstream of a new 
perpendicular dike in the right floodplain (Fig. 6). The comparison of the peak water levels is shown in the scatterplot of Fig. 7. For the reconstruction of the inundation levels and water depths the historical and synthetic generated flood events were considered. Timeseries were divided in nearly independent peak flow periods, from which the maximum flow values were selected and compared (see Fig. 7). The advantage of the applied approach is that small differences in the time of occurrence of peaks hardly affect the scatterplot.

Right Floodplain

\begin{tabular}{|c|c|c|c|c|}
\hline $\operatorname{RMSE}(\mathrm{m})$ & $\begin{array}{c}\text { Mike11 } \\
\text { FRB }\end{array}$ & $\begin{array}{c}\text { InfoWorks- } \\
\text { RS FRB }\end{array}$ & $\begin{array}{c}\text { HEC-RAS } \\
\text { FRB }\end{array}$ & $\begin{array}{c}\text { InfoWorks- } \\
\text { RS FC }\end{array}$ \\
\hline Mike11 - FRB & & 0,971 & 0,952 & 0,904 \\
\hline InfoWorks-RS - FRB & 0,247 & & 0,976 & 0,951 \\
\hline HEC-RAS - FRB & 0,203 & 0,177 & & 0,931 \\
\hline InfoWorks-RS - FC & 0,315 & 0,175 & 0,265 & \\
\hline \multicolumn{5}{|c|}{ Left Floodplain } \\
\hline RMSE (m) & $\begin{array}{l}\text { Mike11 } \\
\text { FRB }\end{array}$ & $\begin{array}{c}\text { InfoWorks- } \\
\text { RS FRB }\end{array}$ & $\begin{array}{c}\text { HEC-RAS } \\
\text { FRB }\end{array}$ & $\begin{array}{c}\text { InfoWorks- } \\
\text { RS FC }\end{array}$ \\
\hline Mike11 - FRB & & 0,967 & 0,949 & 0,949 \\
\hline InfoWorks-RS - FRB & 0,261 & & 0,989 & 0,995 \\
\hline HEC-RAS - FRB & 0,253 & 0,121 & & 0,980 \\
\hline InfoWorks-RS - FC & 0,270 & 0,090 & 0,137 & \\
\hline
\end{tabular}

Table 6. Peak inundation level results for the historical flood events and composite hydrographs.

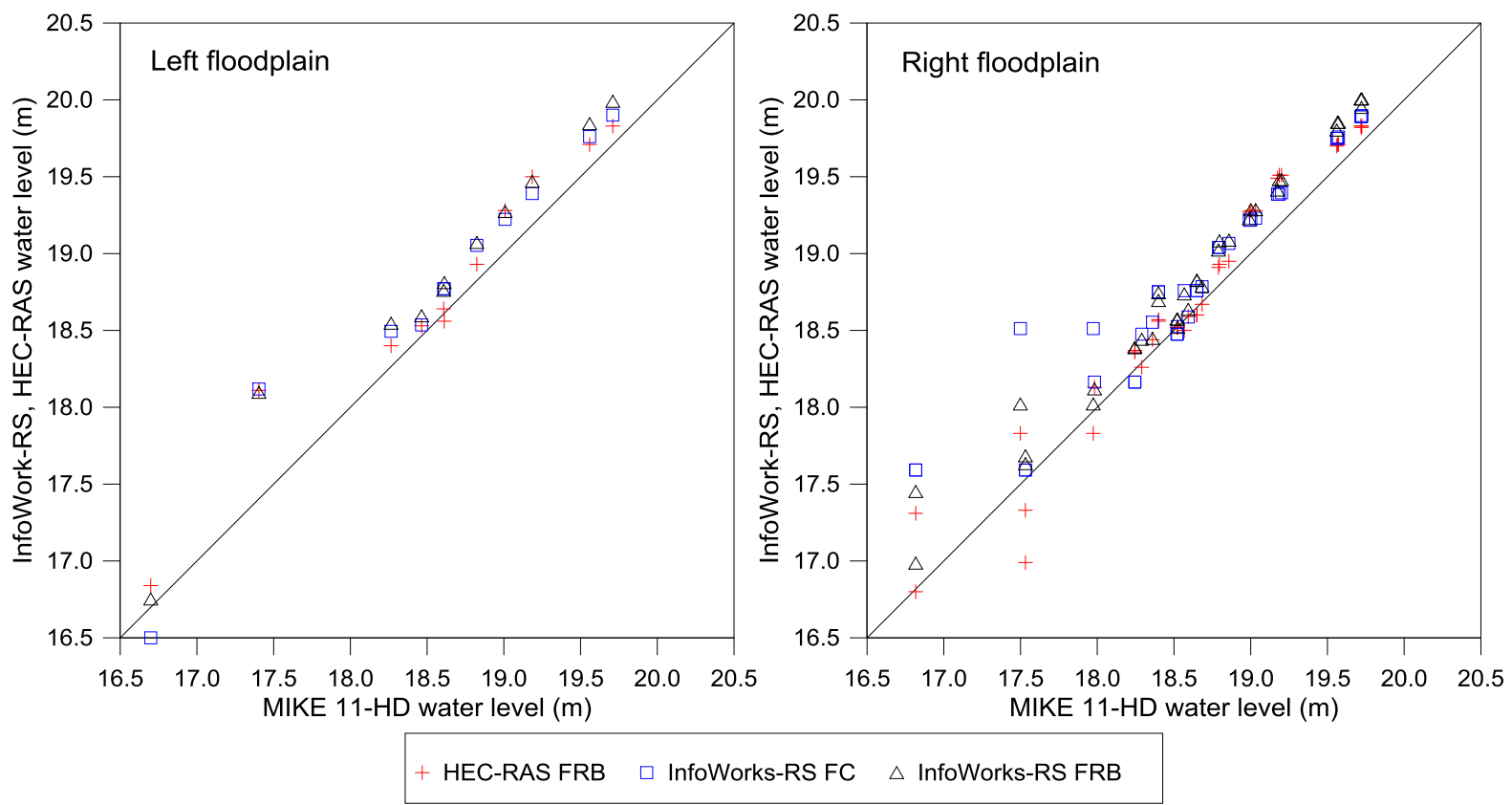

Figure 7. InfoWorks-RS and HEC-RAS versus Mike11 water levels inside the floodplains, based on the historical flood events and the composite hydrographs.

There are no observed water levels available inside the floodplains. Comparison was therefore made between the results of the three modelling packages. In Table 6 the determination coefficients $\left(\mathrm{R}^{2}\right)$ and the RMSE (here considered as root mean square difference) are presented for the right and 
left floodplain for the historical and synthetic events. If only historical events are considered the RMSE is $0,13 \mathrm{~m}$ and $0,18 \mathrm{~m}$ for the right and the left floodplain respectively. A similar result $(0,15 \mathrm{~m})$ is shown by Pender and Neelz (2007) for a quasi 2-D hydrodynamic model with FC approach. Villazón and Willems (2009) reported a RMSE around 0,15 m after a sensitivity analysis of the head loss coefficient for the lateral spills.

The differences between the FC and FRB approaches in InfoWorks-RS are smaller compared with the difference between the Mike11 and the InfoWorks-RS simulation results. Comparison of the results of the software packages revealed that the lowest RMSE came from the comparison of InfoWorks-RS against HEC-RAS. This leads to the conclusion that for the conducted case study differences in the model code and default calibration parameters are higher than the differences in the floodplain schematization approach. Due to the similarities that exist in the calculations of flow over the spills in InfoWorks-RS and HEC-RAS, comparison of both software packages resulted in a high determination coefficient and low RMSE. It is also concluded that comparing Mike11 results against the two approaches in InfoWorks-RS, lower RMSE and higher $\mathrm{R}^{2}$ are obtained with the FRB approach. The same is observed when comparing HEC-RAS against the two approaches in InfoWorks-RS. Therefore, the flow dynamics in the floodplains appear to play an important role in the determination of peak inundation levels inside the floodplains. In Fig. 7, a systematic deviation is observed for the higher synthetic events with return periods longer than 50 years. This is mainly caused by the difference in the spill model structure and the values of the default loss coefficients. Those coefficients control the discharge through the spills based on the water levels. The volume of water that spills through the link channels in Mike11 is lower than the volume of water flowing through the spill units in InfoWorks-RS FRB and FC approaches, and the volume of water that spills through the lateral weir in HEC-RAS, with a mean percentage difference for the historical and synthetic events of $23 \%, 26 \%$ and $17 \%$, respectively. The amount of water that passes through the spills is higher in the InfoWorks-RS and HEC-RAS models (Fig. 7 and Fig. 10).

\subsection{Inundation volumes and areas}

The region of Overboelare was divided in right and left floodplains to calculate the area and volume of water in every floodplain. For the Mike11 model approach floodplains were created using Mike-GIS. Mike-GIS uses the water level simulation results in every node of the quasi 2-D Mike11 model. MikeGIS extrapolates the water level and extends the flooded surface to all the surrounded points in the DEM that have lower elevation. The area and volume of the water inside the floodplains during the flood events were calculated using the ArcView. Also the results of InfoWorks-RS (contour maps) were exported to ArcView and processed to derive the peak flooded area and volume of water stored in each of the floodplains. InfoWorks-RS restricts the inundation area inside the flood compartment (Fig. 4), which for the present case study corresponds to the extent of the cross-sections along the floodplain. In the same way the HEC-GeoRAS extension was used to calculate the flooded areas and volumes (US-ACE, 2002), limiting the inundation area by the first and last cross section. Particularities of the three softwares in the reconstruction of the flooded areas are the cause that for example Mike11/Mike-GIS produces higher flooded areas than InfoWorks-RS and HEC-RAS. In order to have in all three models the same area in which flooding is allowed, the results from MikeGIS were cut down to the same flood compartments in InfoWorks-RS (see Fig. 4). The reduction in area is about $15 \%$ in both floodplains and about $10 \%$ in volume. This new scenario is called "Mike11/Mike-GIS reduced surface area (RSA)".

For measuring the accuracy of simulated inundation volumes and areas, simulation results were compared to available historical inundation maps (ROG maps) (Timbe et al., 2005). Those maps were delineated based on photographs, observations, people interviews and digital elevation data. The corresponding peak flooded areas and the water volumes in the floodplains were calculated based on the digital elevation model (DEM) applying ArcView tools. In Fig. 6, for the same historical event the difference in flooded area is depicted. 


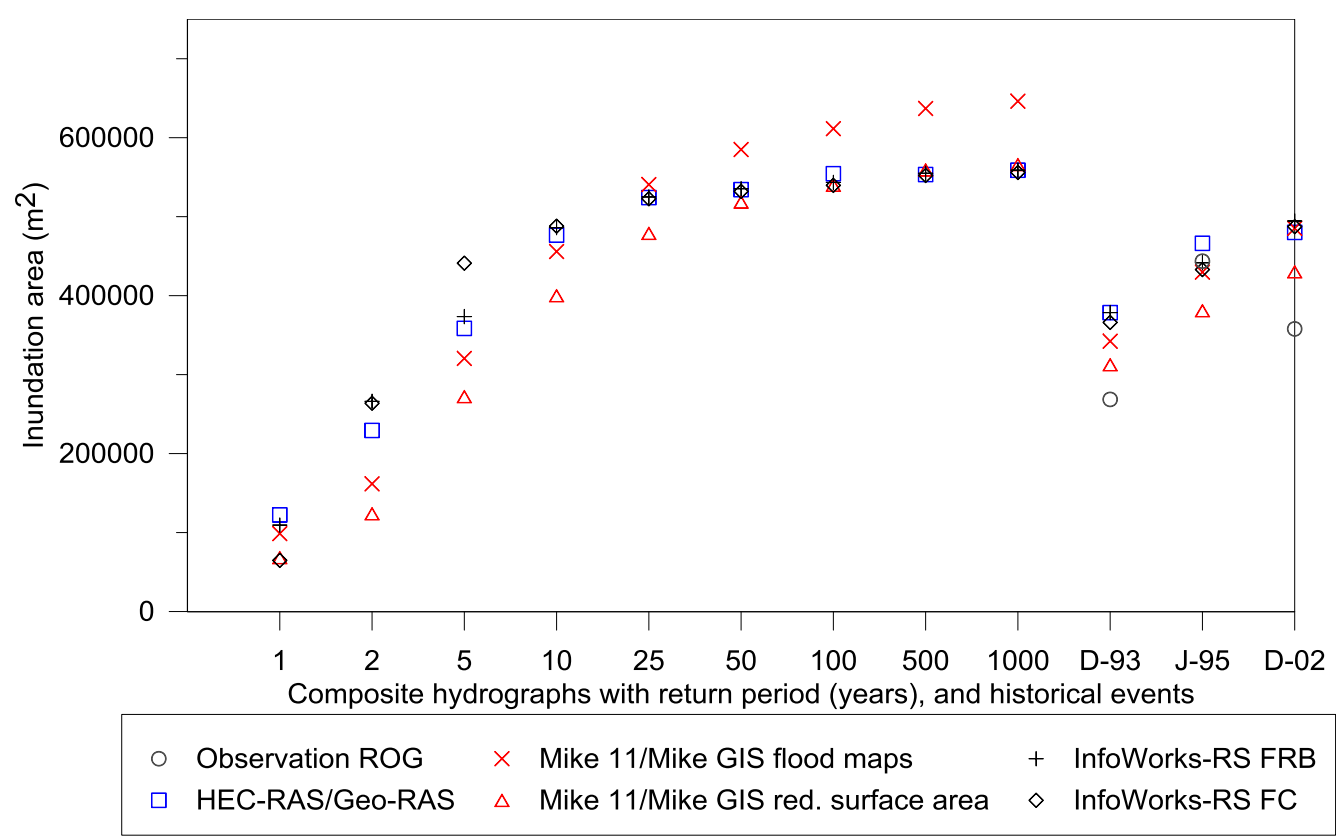

Figure 8. Floodmap inundation areas for the composite hydrographs and the historical flood events (right floodplain).

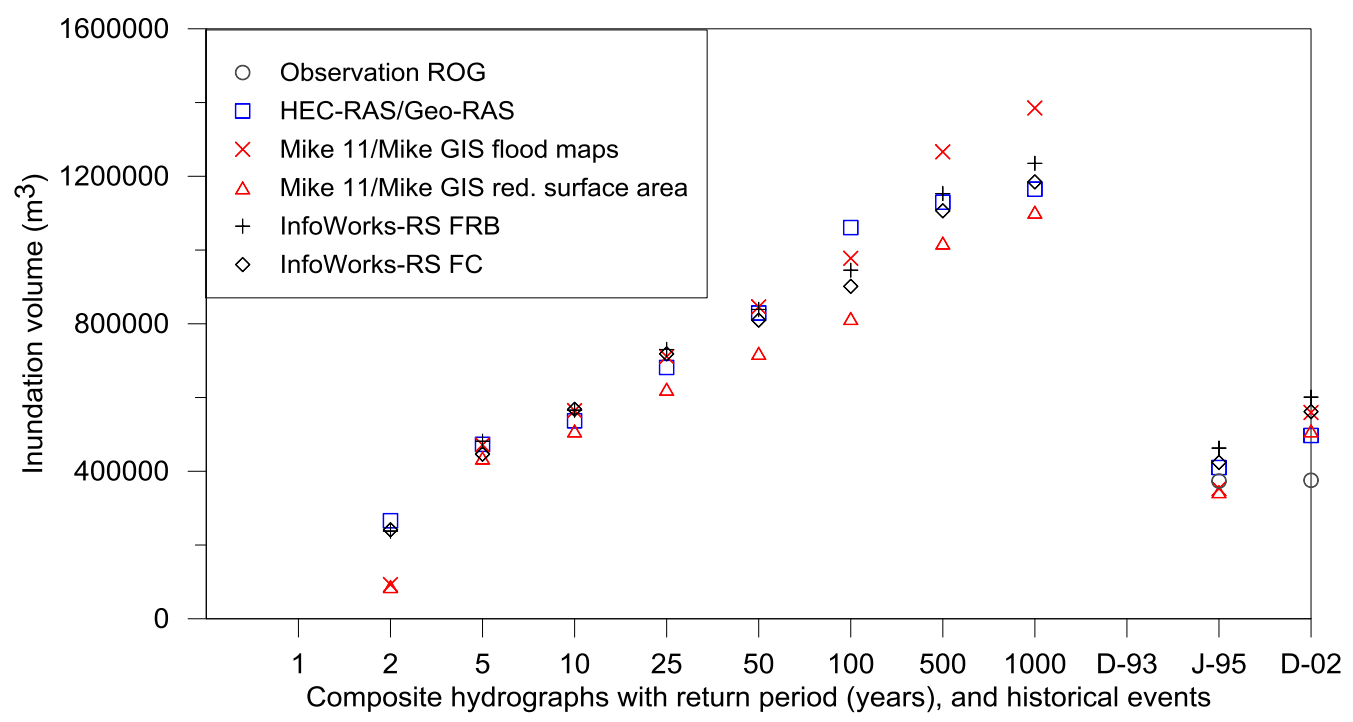

Figure 9. Floodmap inundation volume for the composite hydrographs and the historical flood events (left floodplain).

The peak volumes inside the floodplain were derived combining the flood maps for each peak water level, simulated with the three modeling packages, and the ROG maps. In principle, the calculated volumes should be equal to the volume of water that enters the floodplains through the spill units (InfoWorks-RS, FC and FRB approaches), link channels (Mike11) or lateral weirs (HEC-RAS), till the moment of the peak volume in the floodplain has been reached. The discharge equations of spill units, lateral weirs and link channels are similar; but different in the way the water levels on both sides of the lateral spills are taken into account. In InfoWorks-RS FRB and HEC-RAS each spill considers 4 water level calculation nodes, where a linear water surface profile is assumed between these points (Fig. 3). In Mike11 each link is defined by two points, one on each side and a constant water level is assumed even when the weir has an irregular shape, these differences were also discussed by Van Looveren et al. (2000).

Large differences were observed between the modeled and historical inundation areas and volumes, and this for each of the software packages used (Figs. 8 and 9). However, one has to take 
into consideration that the historical flood maps are only an approximation. Additionally, the software packages do not produce the same output. In Fig. 8 (right floodplain) the flooded surface areas calculated by Mike11/Mike-GIS for the composite hydrographs with return period higher than 50 years are about $10 \%$ higher in comparison with the other approaches. This overestimation is due to the extrapolation of the flooded areas. For the historical event of December 1993 and for the synthetic hydrograph with a return period of one year, the left floodplain is not inundated. Table 7 presents the results of peak inundation areas generated by the three software packages and two approaches of floodplain schematization. The strongest similitude was observed between HEC-RAS-FRB and InfoWorks-RS-FRB.

The peak volume in the floodplain is higher than the maximum volume of water that enters the floodplain through the link channels in Mike11/Mike-GIS (Fig. 10). For the right floodplain the average error is $13,2 \%$ and for the left floodplain $15,4 \%$. Once the restriction to the flood compartment is applied in Mike-GIS, the volume of water inside the right floodplain is almost the same as the volume that enters in the floodplain by the link channels with a reduced average error of $2,2 \%$ overestimation in the left floodplain; nevertheless, in the right floodplain the error is still $8,8 \%$. In InfoWorks-RS an average underestimation of $10,8 \%$ is found for the FC approach and $9,5 \%$ for the FRB approach. HEC-RAS presents an error of $2,4 \%$ for the left floodplain and $10,2 \%$ for the right floodplain.

Table 7. Peak inundation area results for the historical flood events and composite hydrographs.

\begin{tabular}{|c|c|c|c|c|c|}
\hline $\operatorname{RMSE}\left(\mathrm{m}^{2}\right)$ & $\begin{array}{l}\text { Mike11 } \\
\text { FRB }\end{array}$ & $\begin{array}{c}\text { Mike11 RSA } \\
\text { FRB }\end{array}$ & $\begin{array}{l}\text { InfoWorks- } \\
\text { RS FRB }\end{array}$ & $\begin{array}{c}\text { HEC-RAS } \\
\text { FRB }\end{array}$ & $\begin{array}{l}\text { InfoWorks- } \\
\text { RS FC }\end{array}$ \\
\hline Mike11- FRB & & 0,927 & 0,763 & 0,818 & 0,715 \\
\hline Mike11 RSA - FRB & 109785 & & 0,848 & 0,906 & 0,796 \\
\hline InfoWorks-RS - FRB & 116068 & 79127 & & 0,981 & 0,977 \\
\hline HEC-RAS - FRB & 112184 & 67382 & 16704 & & 0,946 \\
\hline InfoWorks-RS - FC & 119574 & 82508 & 17826 & 26972 & \\
\hline
\end{tabular}

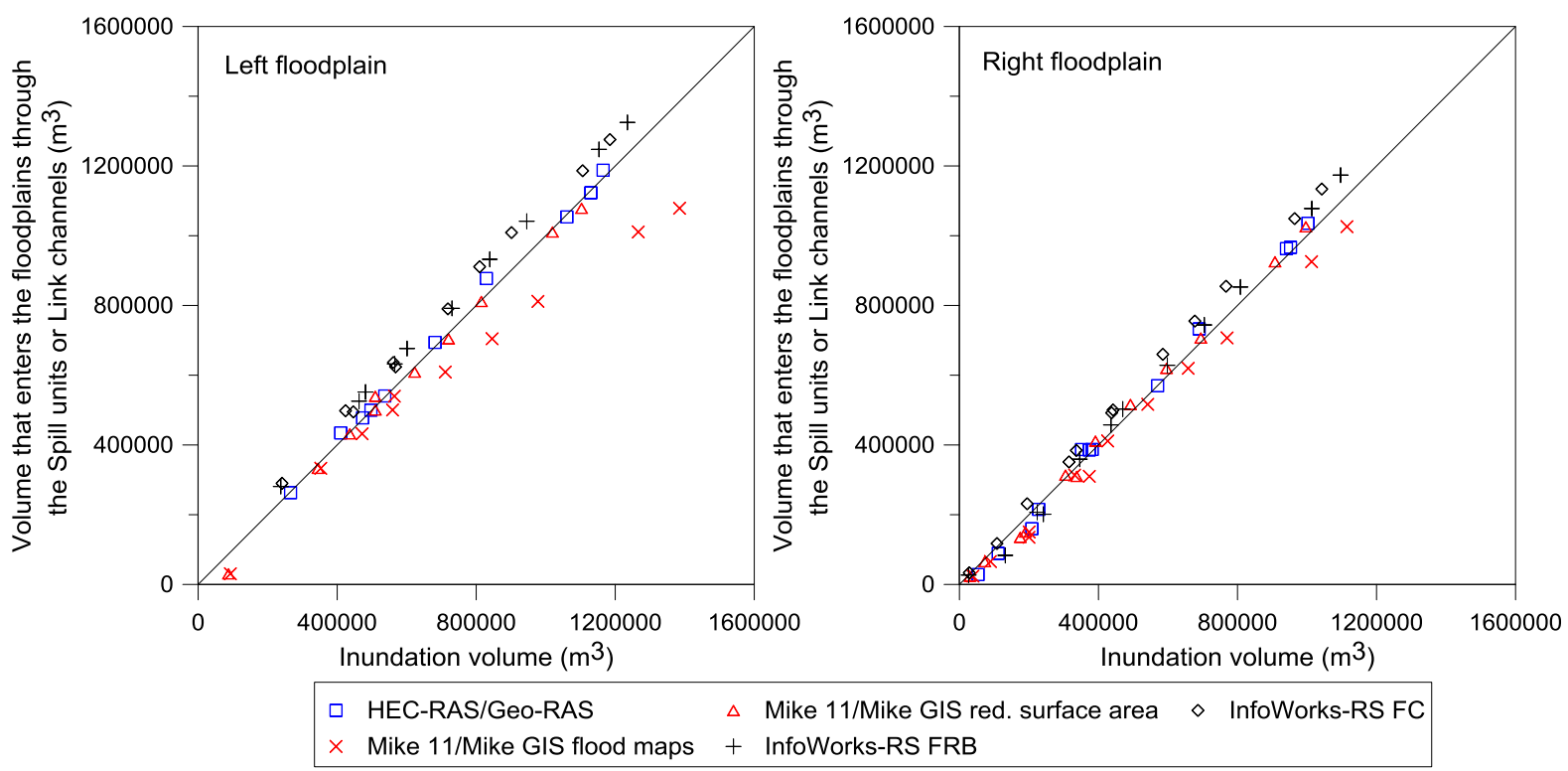

Figure 10. Maximum volume of water that enters the floodplain versus the floodmap maximum inundation volume (right and left floodplain). 
The hypsographic curves in Fig. 11, derived from the model simulation results, are evaluated versus the more accurate ones directly derived from the DEM. Hypsographic curves give a representation of the relationship between the surface area of a basin or floodplain and its depth. With these graphs, the changes in the flood surface areas can be predicted for changes in the water depth. It is clear that the critical factor in the estimation of hypsographic curves is the topography (Horritt and Bates, 2001). The FC approach yields the best results with deviations for the inundation area and flooded volume of $0,66 \%$ and $2,9 \%$. The FRB approach leads to errors up to $0,79 \%$ for the inundation area and 3,8\% for the flooded volume. Inaccuracies of the FRB approach are due to the approximation of the floodplain topography by the $50 \mathrm{~m}$ spaced cross-sections these comparison is made versus the hypsometric curve derived from the DEM, respectively with restrictions by flood compartments (continuous blue line in Fig. 11). Similar errors were found by Casas et al. (2006). Figure 11a shows that the total volume that spills through the link channels (Mike11), spill units (InfoWorks-RS) and lateral structures (HEC-RAS) matches well the volume derived from the DEM based - reduced area hypsographic curve. Also the flooded areas are close to the hypsographic curve derived from the DEM (Fig. 11b).

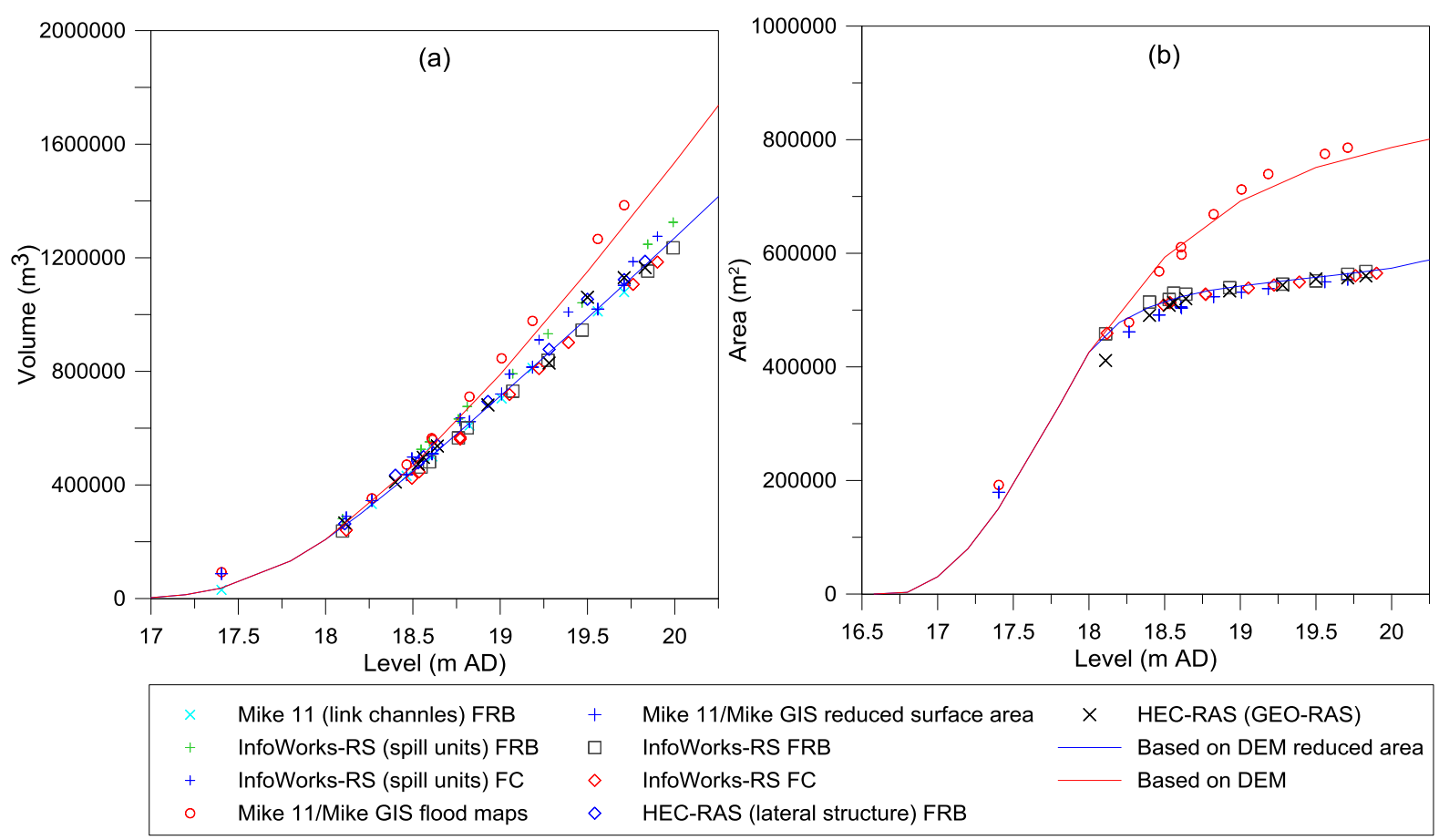

Figure 11. Hypsographic curve (a) volume-level based on the DEM, (b) area-level based on the DEM) for the left floodplain.

\section{CONCLUSIONS AND RECOMMENDATIONS}

The application of three modeling systems and two schematization schemes on the Overboelare floodplain, situated right and left of the Dender River upstream of Geraardsbergen in Belgium, led for all modeling systems to accurate and close results with respect to river water levels and discharges in the Dender River. Root mean square errors are comprised between 5 and $7 \mathrm{~cm}$ for the river water level, and 1 to $2 \%$ for the river discharge. The corresponding errors in the inundation variables in the Overboelare floodplain are an order of magnitude higher. Errors in simulated inundation levels are in the order of $15 \mathrm{~cm}$ for historical events and $25 \mathrm{~cm}$ for extreme synthetic events. Although the three tested software packages solve the Saint-Venant equations in an implicit scheme, found differences are largely due to the method of schematization of the floodplains and the type of hydraulic structures used to mimick the water spill between the river and the floodplain. 
Research revealed that the overestimation of flooded areas and volumes using Mike11 in combination with Mike-GIS can be corrected by constraining the flooded surface area to given flood compartments as done in InfoWorks-RS and HEC-RAS. The same approach as used in the both these software packages has recently been introduced in Mike11, so that this software package produces similar hypsographic curves. The comparative study further revealed that the difference of the volume of water spill over the banks against the inundation volume calculated with GIS for each software package is around $8 \%$. This error increases up to $15 \%$ for the inundation volume and inundation area when inundation areas are mapped combining extrapolation of inundation levels and topography data. Only 2 to $3 \%$ of the total uncertainty in the inundation volumes is caused by the uncertainty in the hypsographic curve, being the consequence of the approximation of the floodplain topography by cross-sections in the FRB approach. The main uncertainty seems to be due to the errors in simulated spill volumes.

The research confirmed the potential of the quasi 2-D hydrodynamic approach as a compromise between the 1- and 2-D approaches used for the modeling of floodplains. The simulation results of HEC-RAS FRB shows the lowest RMSE with the FRB approach in InfoWorks-RS. Good results are also observed with Mike11 FRB. The highest RMSE are found when the comparison between FRB and FC approaches are performed. This leads to the conclusion that when similar schematizations in lateral spills and numerical solution of flow are used (InfoWorks-RS and HEC-RAS), the flow dynamics in the floodplains play an important role. Of course conclusions are case-specific and extrapolations ought to be applied with care. The schematization of the lateral spills and also the numerical solution of the Saint-Venant equations are seen more sensible than the floodplain schematization for peak inundation levels in the floodplains.

\section{ACKNOWLEDGEMENTS}

The research has been supported by a SBA doctoral grant of KU Leuven in the framework of the Selective Bilateral Agreements with Universities in Latin America and by the Research Fund of KU Leuven. The InfoWorks-RS software was made available by Wallingford Software.

\section{REFERENCES}

Abbott, M., F. Ionescu, 1967. On the numerical computation of nearly-horizontal flows. J. Hydraul. Res., 5, 97-117.

Apel, H., A.H. Thienken, B. Merz, G. Blöschl, 2004. Flood risk assessment and associated uncertainty. Nat. Hazards and Earth Syst. Sci., 4, 295-308.

Bates, P.D., A.P.J. De Roo, 2000. A simple raster-based model for flood inundation simulation. $J$. Hydrol., 263, 54-77.

Casas, A., G. Benito, V.R. Thorndycraf, M. Rico, 2006. The topographic data source of digital terrain models as a key element in the accuracy of hydraulic flood modelling. Earth Surf. Process. Landforms, 31(4), 444-456.

Chen, Y.H., 1973. Mathematical modelling of water and sediment routing in natural channels, Ph.D. Dissertation, Department of Civil Engineering, Colorado State University, Ft. Collins, CO.

Crowder, R., A. Pepper, C. Whitlow, 2003. Testing and benchmarking 1D hydraulic river modelling packages. Proc. of the 38th Flood and Coastal Management Conference, Keele University, 16-18 July 2003.

DHI, 2005. Mike11, version 2005. A modelling system for rivers and channels. Reference manual. DHI Water \& Environment, Hørsholm, Denmark.

Evans, E.P., P.H. Von Lany, 1983. A mathematical model of overbank spilling and urban flooding. Int. Conf. on Hydraulic Aspects of Floods and Flood Control, London, BHRA. 
FHWA. 1978. Federal Highway Administration, 1978. Hydraulics of bridge waterways, Hydraulic design series No. 1. U.S. Department of Transportation, Washington D.C.

Hardy, R.J., P.D. Bates, M.G. Anderson, 1999. The importance of spatial resolution in hydraulic model for floodplain environments. J. Hydrol., 216, 124-136.

Halcrow and HR Wallingford, 2006. InfoWorks-RS, version 7.5. Halcrow and HR Wallingford, UK.

Horritt, M.S., P.D. Bates, 2001. Effects of spatial resolution on a raster based model of flood flow. $J$. Hydrol., 253(1-4), 239-249.

Horritt, M.S., P.D. Bates, 2002. Evaluation of 1D and 2D numerical models for predicting river flood inundation. J. Hydrol., 268(1-4), 87-99.

Havnø, K., M.N. Madsen, J. Dørge, 1995. MIKE 11 - a generalized river modelling package. In: Singh V.P. (Ed.). Computer Models of Watershed Hydrology, Water Resources Publications, CO, USA, 733-782.

Helmiö, T., 2005. Unsteady 1D flow model of a river with partly vegetated floodplains-application to the Rhine River. Environ. Modell. Soft., 20(3), 361-375.

Le Dimet, F-X., C. Mazauric, W. Castaings, 2002. Models and data for flood modelling. Proc. of the 2002 Euro-China Co-operation Forum on the Information Society, Beijing, China, April 16-19.

Liggett, J.A., J.A. Cunge, 1975. Numerical methods of solution of the unsteady flow equations. In: Mahmood, K, V. Yervjevich (Eds.) Unsteady Flow in Open Channels, Vol. I, Chapter 4. Water Resources Publications, Ft. Collins, CO.

Markar, M.S., S.Q. Clark, M. Yaowu, Z. Jing, 2004. Evaluation of hydrologic and hydraulic models for real-time flood forecasting use in the Yangtza River catchment. Proc. of the 8th Nat. Conf. of Hydraulics in Water Engineering. Institute of Public Works Engineering Australia.

Mirosław-Światek, D., T. Okruszko, J. Chormanski, 2003. Natural floodplain storage capacity modelling approach. Proc. of the Int. Conf. Towards Natural Flood Reduction Strategies, Warsaw, Poland 6-13 September.

Nash, J.E., J.V. Sutcliffe, 1970. River flow forecasting through conceptual model. J. Hydrol., 10, 282290.

Pender, G., S. Neelz, 2007. Use of computer model of flood inundation to facilitate communication in flood risk management. Environ. Hazard, 7(2), 106-114.

Pistocchi, A., P. Mazzoli, 2002. Use of HEC-RAS and HEC-HMS models with ArcView for hydrologic risk management. In: IEMS 2002 - Proc. of the Int. Environmental Modelling and Software Society Conference, Lugano, Switzerland, 305-310.

Preissmann A., 1961. Propagation des intumescences dans les canaux et rivieres. Presented at the $1 s t$ Congress of the French Association for Computation, Grenoble, France, 1961.

AWZ 2003, S. Rombauts, P. Willems, 2004. Hydrological modelling and composite hydrographs for the river Dender basin (in Dutch). Research project for the Flanders Hydraulics Research Laboratory of the Flemish Government in Belgium. Laboratory of Hydaulics, KU Leuven, Belgium, 5 subreports.

Rungø, M., K.W. Olsen, 2003. Combined 1- and 2- dimensional flood modelling. Proceeding 4th Iranian Hydraulic Conference, 21-23 October, Shriraz, Iran.

Sinnakaudan, S.K., A. Ab. Ghani, C.C. Kiat, 2002. Flood inundation analysis using HEC-6 and ArcView GIS 3.2a. 5th Int. Conf. on Hydroscience and Engineering, Warsaw, Poland.

Sinnakaudan, S.K., A. Ab. Ghani, S. Ahmad, S. Mohd, N.A. Zakaria, 2003. Flood risk mapping for Pari River incorporating sediment transport. Environ. Modell. Soft., 18 (2), 119-130.

Timbe, L., P. Willems, 2007. Performance of 1D and 2D hydrodynamic models for floodplain modelling. Proc. of the Int. Congress on Development Environmental and Natural Resources: Multi-level and Multi-scale Sustainability, 11-13 July, Cochabamba, Bolivia 1, 624-632.

Timbe, L., P. Willems, J. Berlamont, 2005. Validation of a quasi-2D hydrodynamic river flood model using historical and ERS-SAR derived flood maps. XXXI IAHR Conference on "Water Engineering for the Future, Choices and Challenges”, Seoul, Korea 11-16 Sept. 2005, 137-147. 
Tun Lee, K., Y-H. Ho, Y-J. Chyan, 2006. Bridge blockage and overbank flow simulations using HECRAS in the Keelung River during the 2001 Nari typhoon. Technical notes, J. Hydraul. Eng.ASCE. 132(3), 319-323.

US-ACE, 2006. HEC-RAS: River Analysis System, User's Manual, Version 4.0 Beta, US Army Corps of Engineers.

US-ACE, 2002a. HEC-RAS: River Analysis System, Hydraulic Reference Manual, Version 3.1, US Army Corps of Engineers.

US-ACE, 2002b. HEC-GeoRAS: An extension for support of HEC-RAS using ArcView, User's Manual, Version 3.1, US Army Corps of Engineers.

Vaes, G., P. Willems, J. Berlamont, 2000. Selection and composition of representative hydrographs for river design calculation. Int. Conf. on Monitoring catchment water quantity and quality, Gent, Belgium, September 2000.

Vaes, G., P. Willems, 2002. Evaluation of the composite hydrograph method for flood risk estimation (in Dutch). Research project for the Flanders Hydraulics Research Laboratory of the Flemish Government in Belgium, Laboratory of Hydraulics, KU Leuven, Belgium, May 2002, 93 pp.

Van Looveren, R., P. Willems, M. Sas, C. Bogliotti, J. Berlamont, J., 2000. Comparison of the software packages ISIS and Mike11 for the simulation of one-dimensional open channel flow. Hydrosoft 2000, Lisbon, 12-14 Jun 2000, 11 pp.

Van Kalken, T., C. Skotner, M. Mulholland, 2005. Application of an Open, GIS Based Flood Forecast System to the Waikato River, New Zealand. Innovation, Advances and Implementation of Flood Forecasting Technology, 17-19 October, Troms $\varnothing$, Norway.

Villazón, M.F., 2005. Comparison of river hydrodynamic models in a quasi two-dimensional approach. MSc thesis, IUPWARE-Vrij Universiteit Brussel - Katholieke Universiteit Leuven, Belgium.

Villazón, M.F., P. Willems, 2009. The importance of spill conceptualizations and head loss coefficients in a quasi two-dimensional approach for river inundation modelling. Ed. Samuels, P., S. Huntington, W. Allsop, J. Harrop, Flood Risk Management: Research and Practice, FloodRisk 2008 Conference. Oxford, UK, 30 Sept.- 2 Oct. 2008 (pp. 305-315). London: Taylor \& Francis Group.

Warner, J.C., W.R. Geyer, J.A. Lerczak, 2005. Numerical modelling of an estuary: A comprehensive skill assessment. J. Geophys. Res., 110( C05), doi: 10.1029/2004JC002691.

Wermer, M., S. Blazkova, J. Petr, 2005. Spatially distributed observations in constraining inundation modelling uncertainties. Hydrol. Process., 19, 3081-3096.

Wermer, M., 2004. A comparison of flood extent modelling approaches through constraining uncertainties on gauge data. Hydrol. Earth Syst. Sc., 8(6), 1141-1152.

Willems, P., R. Van Looveren, M. Sas, C. Bogliotti, J. Berlamont, 2000. Practical comparison of the modelling systems MIKE11 and ISIS for river flood modelling by the quasi two-dimensional approach. Hydroinformatics 2000, Iowa, 23-27 July 2000, 8 p.

Willems, P., L. Timbe, P. Campling, 2002a. Cross-section processing and DTM correction for quasi 2D floodplain modelling: methodology, application to the Mike11-Dender model, and uncertainty analysis (in Dutch). Research project for the Flanders Hydraulic Research Laboratory of the Flemish Government in Belgium, by K.U.Leuven - SADL and Hydraulics Laboratory, Final report May 2002, 78 p.

Willems, P., G. Vaes, D. Popa, L. Timbe, J. Berlamont, 2002b. Quasi 2D River Flood Modelling. River Flow 2002- Proceeding of the International Conference on Fluvial Hydraulics, D. Bousmar \& Y. Zech, (Editors), Swets \& Zeitlinger, Lisse, The Netherlands.

AWZ 2003, P. Willems, S. Rombauts, 2004. Setup of the numeric hydrological model and formulation of the composite hydrograph for the Dender basin. Research Report for the Flanders Hydraulics Research Administration (WL Borgenhout), IMDC \& KU Leuven (in Dutch).

Wilmott, C.J., 1981. On the validation of models. Physical Geography, 2, 184-194. 
MASKANA, Vol. 4, No. 1, 2013

Yang, J., R.D. Townsend, B. Daneshfar, 2006. Applying the HEC-RAS model and GIS techniques in river network floodplain delineation. Can. J. Civil Eng., 33, 19-28. 